\title{
ASSESSING SOIL QUALITY THROUGH SOIL CHEMICAL PROPERTIES AND ENZYME ACTIVITIES IN SEMIARID AREA, IRAN
}

\author{
TEIMOURI, M. ${ }^{1}-$ MohAMAdi, P. ${ }^{1 *}-$ JALILI, A. $^{2}-$ DiCK, W. A. ${ }^{3}$ \\ ${ }^{I}$ Microbiology Department, Biological Science Faculty, Alzahra University \\ Vanak Village Street, Tehran 1993891176, Iran, I. R. \\ (phone: +98-21-8804-4040; fax: +98-21-8803-5187) \\ ${ }^{2}$ Research Institute of Forests and Rangelands, Agricultural Research Education and Extension \\ Organization (AREEO), Tehran-Karaj Highway, Azadshahr, P.O. Box 13185-116, Tehran, \\ Iran, I. R. (phone: +98-21-4478-7280; fax: +98-21-4478-7223) \\ ${ }^{3}$ School of Environment and Natural Resources, The Ohio State University, Wooster, $\mathrm{OH}$ \\ 44691-4096, USA (phone: +1-330-263-3877; fax: +1-330-263-3658) \\ *Corresponding author \\ e-mail: p.mohammadi@alzahra.ac.ir; phone: +98-21-8804-4040; fax: +98-21-8803-5187 \\ (Received $3^{\text {rd }}$ Dec 2017; accepted $7^{\text {th }}$ Mar 2018)
}

\begin{abstract}
Semiarid ecosystems are more sensitive to environmental changes than other terrestrial ecosystems, which makes their monitoring very important. Determining soil quality is critical to precise monitoring of semiarid area, and its evaluation involves the assessment of soil properties. In this study, the soil chemical properties and enzyme activities were measured and compared in order to determine soil quality. Four plots were chosen in the cold and warm sites in the Khabr national park and Ruchun wildlife refuge with grazed and not grazed areas. Samples of surface soil $(0-10 \mathrm{~cm})$ were collected in spring and autumn. The results showed that chemical properties of the soils were significantly affected by site (soil organic carbon, total nitrogen, available phosphorus and soil moisture) and season ( $\mathrm{pH}$, total nitrogen, available phosphorus and soil moisture) but not by grazing. All assayed enzyme activities were significantly influenced by site and season. Alkaline phosphatase activity was affected by grazing, too. Soil chemical properties (soil organic carbon, total nitrogen, and available phosphorus content and soil moisture) and enzyme activities (acid phosphatase, alkaline phosphatase, invertase, $\beta$-glucosidase, urease and arylsulfatase) showed higher value at cold sites. The positive correlation between all assayed enzymes and soil organic carbon $(r=0.189-0.639)$ indicated the important role of soil organic carbon availability in soil enzyme activities. Seasonal variation was observed in soil chemical properties except for electrical conductivity. In addition, temporal variation was observed in enzyme activities with more activity in spring samples except for arylsulfatase activity. According to more value in nutrient content and enzyme activities, it can be concluded that soil at cold sites have higher quality than warm sites. In conclusion, the warm sites with poor soil quality need more concern to be protected.
\end{abstract}

Keywords: grazing, monitoring, seasonal, semiarid, soil quality

\section{Introduction}

Semiarid ecosystems approximately cover $40 \%$ of the Earth's land and are increasing in proportion due to global warming and consequent desertification. The soils, in these ecosystems, characteristically contain less organic matter and plant biomass (ReyesReyes, 2007). The fragility of soil in semiarid environments, caused by low organic matter content, lack of vegetation exposes soil to wind and soil erosion, and salty crusts impede root growth, makes soil quality monitoring and management imperative. 
Various physical, chemical, biological and biochemical indicators have been used to estimate soil quality. It is important to take into account sensitivity to soil management in a wide range, sampling error, cost of measurement and required time. The measurement of soil enzyme activities provides an early indication of changes in soil quality, as they are involved in the mineralization of nutrients such as $\mathrm{N}, \mathrm{P}$ and $\mathrm{C}$ (Trasar-Cepeda et al., 2008). Soil enzymes participate in almost every transformation process of decomposition and play a central role in maintaining soil fertility by releasing mineral nutrients from complex organic resources (Baldrian and Stursová, 2010). Since soil enzyme activities are linked with several ecosystem processes and exhibit rapid response to both natural and anthropogenic disturbances, they have been adopted as a suitable indicators for soil quality (Das and Varma, 2010).

Iran, with an area of 164 million hectares, is located in the mid-latitude belt of arid and semiarid regions of the Earth. The arid and semiarid regions cover more than $60 \%$ of the country, which is vulnerable to land degradation and, in consequence, desertification due to the increasing population pressure on the land due to grazing and the consumption of water resources (Amiraslani and Dragovich, 2011). The Khabr National Park and the Ruchun Wildlife Refuge is located in the southeast of Iran with various ecological systems and different habitats for plants and animals (Najmizadeh and Yavari, 2006). While the quality of a soil is related to its physical, chemical and biological properties, only several studies has been conducted on physical processes, chemical properties and the biology of soil flora and fauna in the semiarid areas of Iran (Bagheri et al., 2009; Rajabi et al., 2011; Shirvani, 2012; Sharafatmandrad et al., 2014; Mirzaei et al., 2017). There is very little information on soil biological indicators in the Iranian semiarid areas (Raiesi and Riahi, 2014; Kabiri et al., 2016). Indeed, there has not been any study on soil enzyme activities in the Khabr National Park and the Ruchun Wildlife Refuge. Therefore, this study addresses the information gap that exists on the effects of site, season and grazing on soil enzyme activities as important soil quality indicators in this park, which is needed to aide in the overall quality assessment of the ecosystems contained within this park. It was hypothesized that soil chemical properties and enzyme activities are different at cold and warm sites and is also affected by season and grazing. For this purpose, the variation in soil chemical properties and enzyme activities was studied of selected cold and warm sites, which were either grazed or not grazed in spring and autumn seasons.

\section{Materials and methods}

\section{Field site, experiment design and soil sampling}

The study area is located in the southeast of Iran within the semiarid steppe region of Khabr National Park and Ruchun Wildlife Refuge, Kerman province, Iran. This park extends from $28^{\circ} 28^{\prime}$ to $28^{\circ} 58^{\prime} \mathrm{N}$ and from $56^{\circ} 02^{\prime}$ to $56^{\circ} 38^{\prime}$ E. The mean annual temperature and precipitation varies between $17.5-21.0^{\circ} \mathrm{C}$ and $200-350 \mathrm{~mm}$, respectively. Mean monthly temperature and precipitation has been given in Figure 1. Two plots at the cold sites and two plots at the warm sites were selected as sampling plots for this study. The altitude of the warm site is $1,707 \mathrm{~m}$ above sea level (a.s.l) and the vegetation is dominated by Artemisia siberi. The cold sites have an altitude of 2,365 $\mathrm{m}$ (a.s.l), and the vegetation is dominated by Stipa hassknechti and A. siberi. At both the cold (C) and warm (W) sites, grazed (G) and not grazed (NG) areas were selected (Fig. 2). Thus, in the analysis, four treatments were considered as follows: (1) cold-grazed 
(CG), (2) cold-not grazed (CNG), (3) warm-grazed (WG) and (4) warm-not grazed (WNG).

Eight soil samples were collected from the top $10 \mathrm{~cm}$ of soil from a plot area $100 \times 100 \mathrm{~m}$ in mentioned treatments in spring ( $\mathrm{S}$, June) and autumn (A, November). In the laboratory, collected samples were thoroughly mixed and homogenized by sieving through a $2 \mathrm{~mm}$ sieve. Room-temperature, dried soil was used in chemical analysis. Enzyme activities assays were done on soil samples stored at $-20{ }^{\circ} \mathrm{C}$.

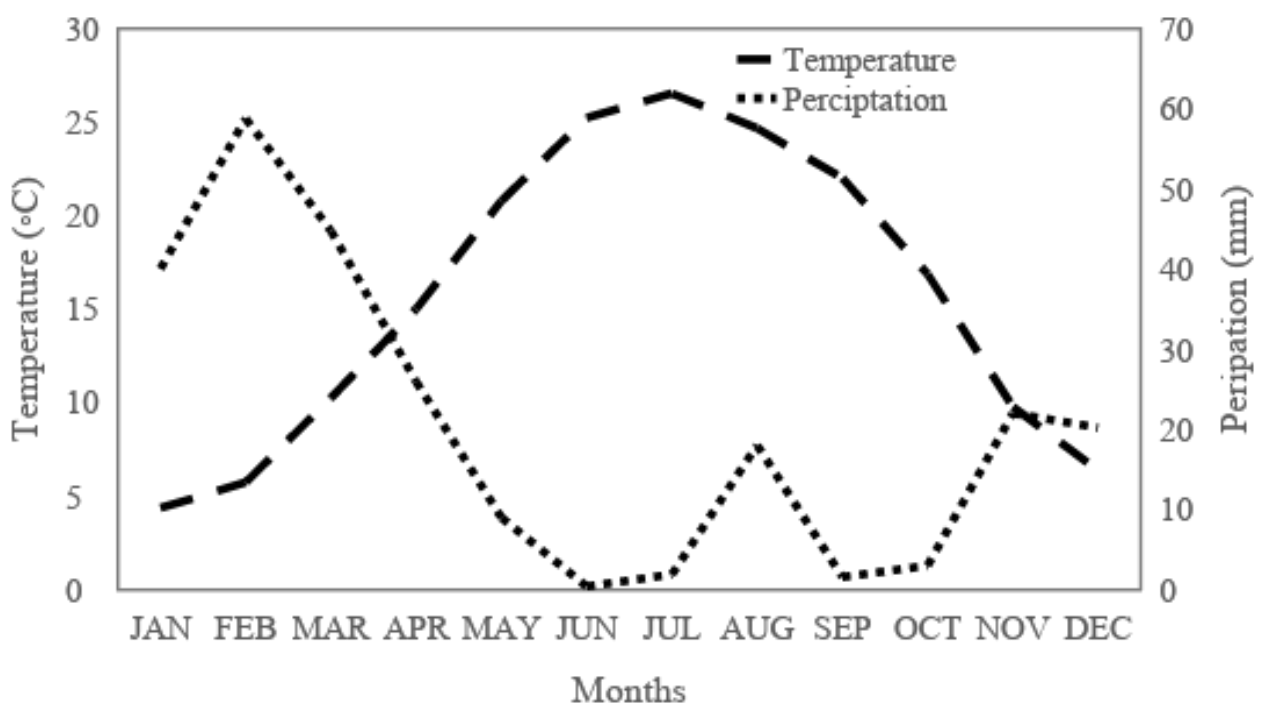

Figure 1. Mean monthly temperature and precipitation during 2007-2017 at the Khabr National Park and Ruchun Wildlife Refuge
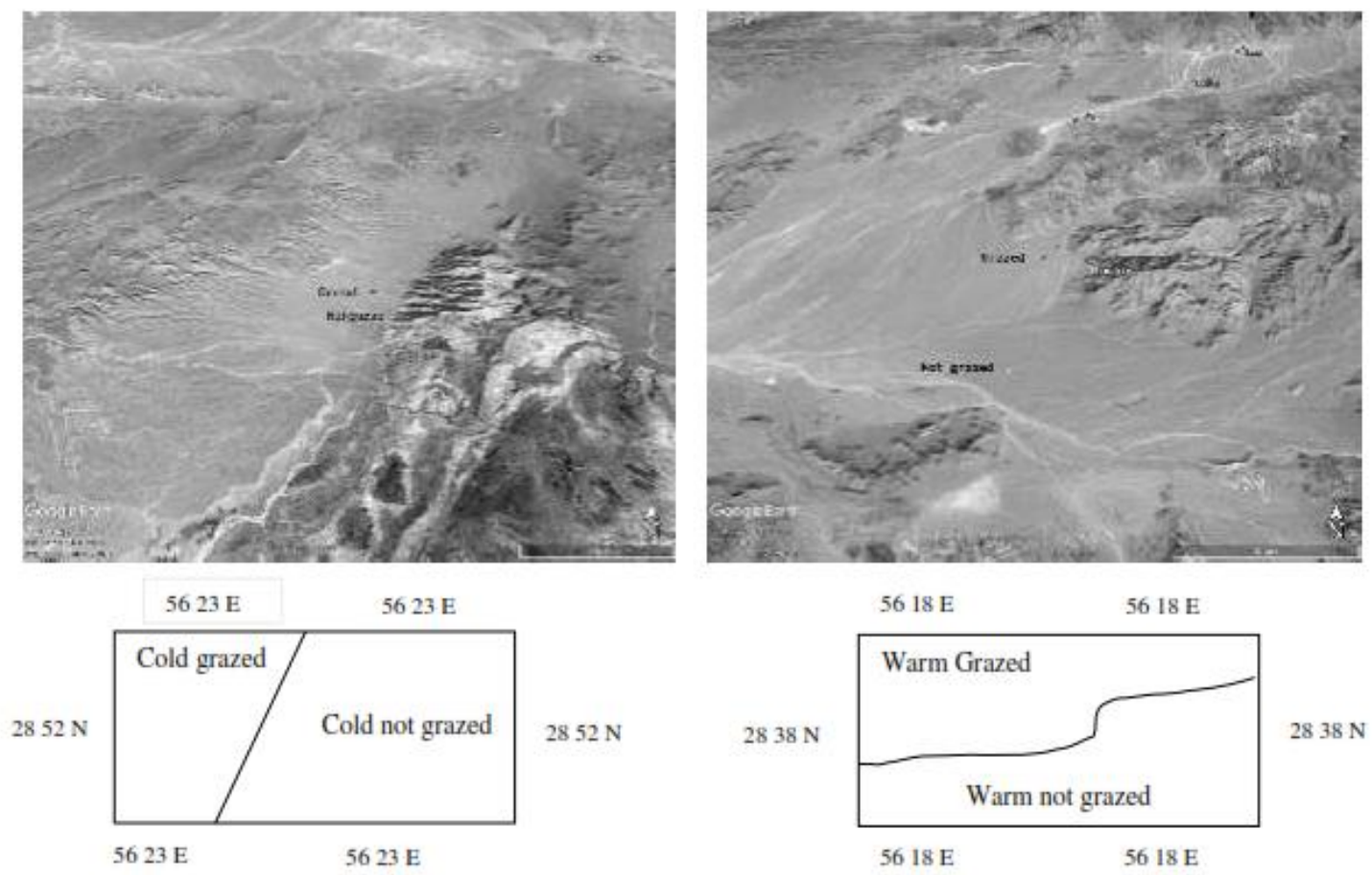

Figure 2. Precise location of grazed and not grazed areas at the cold (left) and the warm (right) sites (Google Earth) 


\section{Soil chemical properties}

Soils chemical properties values were measured based on standard methods. The soil $\mathrm{pH}$ and electrical conductivity were measured in soil suspensions (Mclean, 1982). Soil water content was measured by drying soil samples at $105{ }^{\circ} \mathrm{C}$ (Schlichting and Blume, 1966). The soil texture was determined by the hydrometric method (Toogood, 1958). A wet digestion method (Walkley and Black, 1934) was used to measure soil organic carbon. The soil available phosphorus (AP) was determined using the molybdenum blue method (Olsen and Summers, 1982) following extraction by sodium bicarbonate. A micro Kjeldahl method (Bremner and Mulvaney, 1982) was used to measure total nitrogen $(\mathrm{TN})$ in soil samples.

\section{Soil enzyme activities}

The activity of seven hydrolytic enzymes was determined using their specific substrates. Acid phosphatase, alkaline phosphatase, arylsulfatase and $\beta$-glucosidase activity were measured in soil samples based on assays described by Schinner et al. (1996). Invertase and urease activity were determined as described by Schinner and von Mersi (1990) and Kandeler and Gerber (1988), respectively. The enzyme activities were assayed in duplicates at their optimal $\mathrm{pH}$. The controls were soil samples to which substrate were added after the incubation step. An outline of studied enzymes, their substrate and assay $\mathrm{pH}$ has been given in Table 1 .

Table 1. Soil enzymes assayed in this study with their substrates and assay conditions

\begin{tabular}{c|c|c}
\hline Enzyme & Substrate & Assay condition (pH) \\
\hline Alkaline Phosphatase & p-nitrophenyl phosphate hexahydrate & 11 \\
\hline Acid Phosphatase & p-nitrophenyl phosphate hexahydrate & 6.5 \\
\hline$\beta$-glucosidase & p-Nitrophenyl- $\beta$-D-glucopyranoside & 6 \\
\hline Invertase & Sucrose & 5.5 \\
\hline Urease & Urea & 7 \\
\hline Aryl Sulfatases & p-Nitrophenyl sulfate & 5.8 \\
\hline
\end{tabular}

\section{Statistical analysis}

The data of variables were checked for their normality with Shapiro-Wilk test. If necessary, the variables were transformed by Jonson transformation using Minitab software to improve normality. Three -way analysis of variance (ANOVA) was used to assessment significant effects of site, season and grazing on soil chemical and enzyme activities. Non-normal data were analyzed using Mann-Whitney U test to evaluate the main effects of studied factors. Mean comparisons were evaluated by the Least Significant Difference (LSD) test at the 5\% level of significance. In order to explore links between soil chemicals and enzyme activities, Pearson's correlations were calculated. Reporting of data as histograms was conducted using Microsoft Excel 2010. 


\section{Results}

\section{Soil chemical properties}

The soil types are Haplic Calcisoils according to according to the soil classification of the World Reference Base (WRB) for Soil Resources. All soils were characterized as sandy loam texture with an average of $10 \%$ clay, $30 \%$ silt and $60 \%$ sand. None of soil chemical properties was affected by grazing (Table 2). Only the effect of season was significant $(\mathrm{p}<0.01)$ on soil $\mathrm{pH}$ (Table 3$)$. The $\mathrm{pH}$ value was higher in the soil samples, collected in autumn (November) than soil samples collected in spring (June) samples (Table 4). The effect of site and season was significant $(\mathrm{p}<0.01)$ on total nitrogen $(\mathrm{TN})$ and available P (AP) but not grazing (Table 2). Whereas the spring samples had higher available $\mathrm{P}$ than autumn samples, the value of TN was more in autumn samples than spring samples (Table 4). In addition, site and season interaction was significant $(\mathrm{p}<0.01)$ on AP (Table 2) with the highest available AP in samples taken from cold sites in spring (Fig. 3).

Table 2. Mean squares of studied factors and their interactions for normalized parameters

\begin{tabular}{c|c|c|c|c}
\hline \multirow{2}{*}{ Treatments } & \multicolumn{4}{|c}{ Independent variables } \\
\cline { 2 - 5 } & $\mathbf{E C}$ & $\mathbf{T N}$ & $\mathbf{A P}$ & $\mathbf{S M}^{\mathbf{T}}$ \\
\hline Site & $0.001^{\mathrm{ns}}$ & $37.20^{* *}$ & $324.00^{* *}$ & $13.88^{* *}$ \\
Season & $0.08^{\mathrm{ns}}$ & $6.45^{* *}$ & $196.00^{* *}$ & $26.62^{* *}$ \\
Season $\times$ site & $0.049^{\mathrm{ns}}$ & $0.20^{\mathrm{ns}}$ & $676.00^{* *}$ & $0.03^{\mathrm{ns}}$ \\
Replication $\times($ season $\times$ site $)$ & 1.57 & 0.49 & 12.28 & 0.14 \\
Grazing & $0.03^{\mathrm{ns}}$ & $0.04^{\mathrm{ns}}$ & $36.00^{\mathrm{ns}}$ & $0.03^{\mathrm{ns}}$ \\
Season $\times$ grazing & $0.41^{\mathrm{ns}}$ & $0.09^{\mathrm{ns}}$ & $36.00^{\mathrm{ns}}$ & $0.23^{\mathrm{ns}}$ \\
Site $\times$ grazing & $0.02^{\mathrm{ns}}$ & $0.01^{\mathrm{ns}}$ & $36.00^{\mathrm{ns}}$ & $0.12^{\mathrm{ns}}$ \\
Season $\times$ site $\times$ grazing & $0.07^{\mathrm{ns}}$ & $0.03^{\mathrm{ns}}$ & $36.00^{\mathrm{ns}}$ & $0.04^{\mathrm{ns}}$ \\
Error & 0.001 & 0.27 & 12.35 & 0.15 \\
Total & 53.73 & 66.07 & 2030.00 & 49.36 \\
\hline
\end{tabular}

Significant effect at $\mathrm{p}<0.05$ and $\mathrm{p}<0.1$ levels are indicated by $*$ and $* *$, respectively. ${ }^{\mathrm{ns}}$ indicates no significant effect. EC: electrical conductivity, TN= total nitrogen, AP: Available phosphorus and SM: Soil moisture. Transformed data were used in EC and TN analysis.

Table 3. Level of significance non-normalized parameters by using non-parametric MannWhitney $U$ test

\begin{tabular}{c|c|c|c}
\hline \multirow{2}{*}{ Comparison source } & \multicolumn{3}{|c}{ Independent variables } \\
\cline { 2 - 4 } & $\mathbf{p H}$ & SOC & ACP \\
\hline Site (cold and warm) & $37.00^{\mathrm{ns}}$ & $2.00^{* *}$ & $319.00^{* *}$ \\
Season (spring and autumn) & $1.00^{* *}$ & $418.00^{\mathrm{ns}}$ & $0.00^{* *}$ \\
Grazing (Grazed with not grazed) & $443.00^{\mathrm{ns}}$ & $474.50^{\mathrm{ns}}$ & $494.00^{\mathrm{ns}}$ \\
\hline
\end{tabular}

Significant effect at $\mathrm{p}<0.05$ and $\mathrm{p}<0.1$ levels are indicated by $*$ and $* *$, respectively. ${ }^{\mathrm{ns}}$ indicates no significant effect $\mathrm{SOC}$ : soil organic carbon, $\mathrm{ACP}=$ acid phosphatase. 


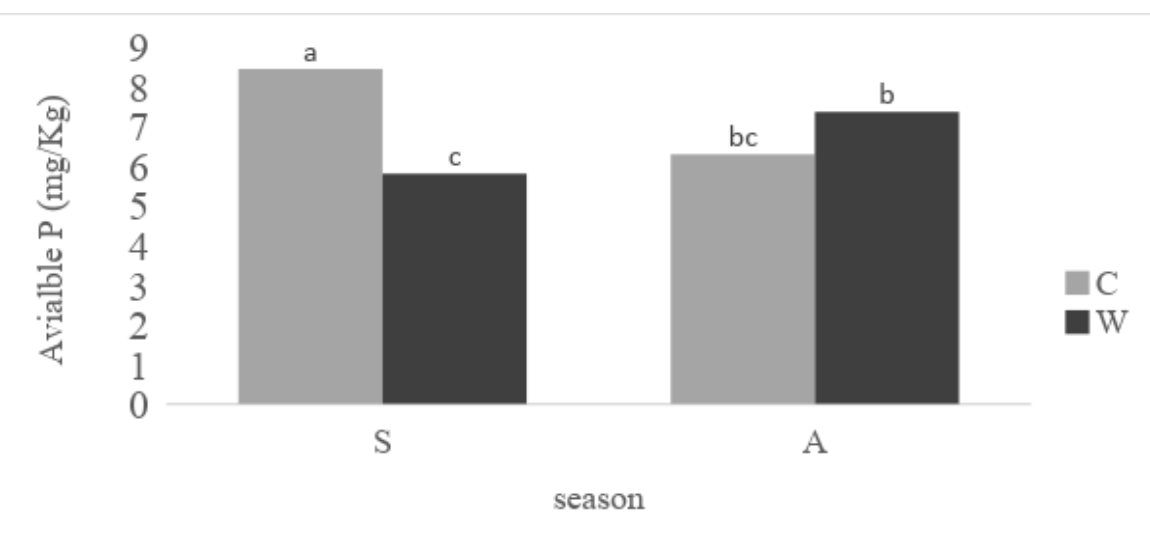

Figure 3. Phosphorus availability in soil developed under interaction of site $(C=$ cold and $W=$ warm) and season ( $S=$ spring and $A=$ autumn) conditions. Different letters indicate significant difference at the $p<0.05$ level

As given in Table 3, only site had significant $(\mathrm{p}<0.01)$ effect on soil organic carbon (SOC) with more value in cold sites (Table 4). Measured soil water content showed significantly higher values in cold sites and autumn samples in comparison to warm sites and spring samples, respectively (Tables 2 and 4).

Table 4. Mean comparison $(n=8)$ between sites and season in soil chemical properties

\begin{tabular}{c|cc|cc}
\hline \multirow{2}{*}{ Soil chemical } & \multicolumn{2}{|c|}{ Site } & \multicolumn{2}{c}{ Season } \\
\cline { 2 - 5 } & Cold & Warm & Spring & Autumn \\
\hline $\mathrm{pH}$ & $7.75^{\mathrm{a}}$ & $7.85^{\mathrm{a}}$ & $7.9^{\mathrm{b}}$ & $8.3^{\mathrm{a}}$ \\
Total nitrogen (\%) & $0.08^{\mathrm{a}}$ & $0.05^{\mathrm{b}}$ & $0.06^{\mathrm{b}}$ & $0.07^{\mathrm{a}}$ \\
Available phosphorus & $35.00^{\mathrm{a}}$ & $30.5^{\mathrm{b}}$ & $34.50^{\mathrm{a}}$ & $31.00^{\mathrm{b}}$ \\
Soil organic carbon (\%) & $0.65^{\mathrm{a}}$ & $0.29^{\mathrm{b}}$ & $0.39^{\mathrm{a}}$ & $0.45^{\mathrm{a}}$ \\
Soil moisture (\%) & $4.44^{\mathrm{a}}$ & $1.32^{\mathrm{b}}$ & $0.93^{\mathrm{b}}$ & $4.83^{\mathrm{a}}$ \\
\hline
\end{tabular}

Different letters show significant difference at $p<0.05$ level.

\section{Soil enzyme activities}

As shown in Table 5, the effect of site $(\mathrm{p}<0.01)$, season $(\mathrm{p}<0.01)$ and grazing $(\mathrm{p}<0.05)$ was significant on alkaline phosphatase activity (Table 5). Activity of soil alkaline phosphatase decreased by 28,22 and $15 \%$ in warm sites, autumn samples and not grazed areas in comparison to cold sites, spring samples and grazed areas, respectively (Table 6). The effect of site and season was significant on acid phosphatase but not grazing (Table 3). Acid phosphatase activity decreased by 32 and $66 \%$ in warm site and autumn samples in comparison with cold sites and spring samples (Table 6), respectively.

The results indicated significant effect $(\mathrm{p}<0.01)$ of site and season on $\beta$-glucosidase and invertase activity (Table 5). The $\beta$-glucosidase activity decreased by 33 and $52 \%$ in warm site and autumn samples (Table 6). Grazing did not affect significantly $\beta$-glucosidase activity. However, the interaction of site and grazing was significant $(\mathrm{p}<0.05)$ on its activity (Table 5 and Fig. 4). 
Table 5. A summary of the levels of treatment significance on soil enzyme activities

\begin{tabular}{|c|c|c|c|c|c|}
\hline Treatments & ALP & $\beta$-Glu & INV & UR & $\mathbf{A S}$ \\
\hline Site & $95256.33^{* *}$ & $63936.3^{* *}$ & $13.88^{* * *}$ & $35.57^{\mathrm{ns}}$ & $12121.1^{* *}$ \\
\hline season & $40290.02^{* *}$ & $186981.6^{* *}$ & $26.62 * *$ & $5353.56^{*}$ & $7333.90^{* *}$ \\
\hline Season $\times$ site & $4.29^{\mathrm{ns}}$ & $6306.15^{\mathrm{ns}}$ & $0.03 \mathrm{~ns}$ & $111.22^{\mathrm{ns}}$ & $107.53^{\text {ns }}$ \\
\hline Replication $\times($ season $\times$ site $)$ & 875.566 & 2127.32 & 0.14 & 547.58 & 128.46 \\
\hline Season $\times$ grazing & $64.98^{\text {ns }}$ & $219.99^{\text {ns }}$ & $0.24 \mathrm{~ns}$ & $178.05^{\mathrm{ns}}$ & $191.01^{\mathrm{ns}}$ \\
\hline Grazing & $6331.98^{*}$ & $3715.97^{\mathrm{ns}}$ & $0.03 \mathrm{~ns}$ & $850.08^{\mathrm{ns}}$ & $21.59^{\mathrm{ns}}$ \\
\hline Site $\times$ grazing & $503.16^{\mathrm{ns}}$ & $20155.13^{*}$ & $0.12 \mathrm{~ns}$ & $67.22^{\mathrm{ns}}$ & $387.17^{\mathrm{ns}}$ \\
\hline Season $\times$ site $\times$ grazing & $474.31^{\mathrm{ns}}$ & $6395.40^{\mathrm{ns}}$ & $0.04 \mathrm{~ns}$ & $861.35^{\mathrm{ns}}$ & $15.38^{\mathrm{ns}}$ \\
\hline Error & 943.27 & 316.98 & 0.15 & 1000.82 & 162.56 \\
\hline Total & 193852.42 & 43578.24 & 49.35 & 50811.55 & 28586.39 \\
\hline
\end{tabular}

Significant effects at the $\mathrm{p}<0.05$ and $\mathrm{p}<0.1$ levels are indicated by $*$ and ${ }^{* *}$, respectively. ${ }^{\text {ns }}$ indicates no significant effect. AlP: alkaline phosphatase, $\beta$-Glu: $\beta$-glucosidase, INV: invertase, UR: urease and AS: arysulfatase. Transformed data were used in INV analysis.

Table 6. Mean comparison $(n=8)$ between sites, season and grazing on soil enzyme activities

\begin{tabular}{c|cc|cc|cc}
\hline \multirow{2}{*}{ Enzyme } & \multicolumn{2}{|c|}{ Site } & \multicolumn{2}{c|}{ Season } & \multicolumn{2}{c}{ Grazing } \\
\cline { 2 - 7 } & Cold & Warm & Spring & Autumn & Grazed & Not grazed \\
\hline Alkaline phosphatase & $240.68^{\mathrm{a}}$ & $163.71^{\mathrm{b}}$ & $227.37^{\mathrm{a}}$ & $177.19^{\mathrm{b}}$ & $162.95^{\mathrm{a}}$ & $147.71^{\mathrm{b}}$ \\
Acid phosphatase & $262.04^{\mathrm{a}}$ & $187.89^{\mathrm{b}}$ & $374.00^{\mathrm{a}}$ & $75.93^{\mathrm{b}}$ & $245.12^{\mathrm{a}}$ & $238.75^{\mathrm{a}}$ \\
$\beta$-Glucosidase & $186.91^{\mathrm{a}}$ & $123.73^{\mathrm{b}}$ & $209.38^{\mathrm{a}}$ & $101.28^{\mathrm{b}}$ & $189.45^{\mathrm{a}}$ & $175.12^{\mathrm{a}}$ \\
Invertase & $2248.39^{\mathrm{a}}$ & $528.04^{\mathrm{b}}$ & $339.53^{\mathrm{a}}$ & $243.69^{\mathrm{b}}$ & $1491.45^{\mathrm{a}}$ & $1284.7^{\mathrm{a}}$ \\
Urease & $52.01^{\mathrm{a}}$ & $53.99^{\mathrm{a}}$ & $61.99^{\mathrm{a}}$ & $43.70^{\mathrm{b}}$ & $56.49^{\mathrm{a}}$ & $49.2^{\mathrm{a}}$ \\
Arylsulfatase & $120.7^{\mathrm{a}}$ & $99.54^{\mathrm{b}}$ & $102.60^{\mathrm{b}}$ & $124.01^{\mathrm{a}}$ & $111.04^{\mathrm{a}}$ & $115.4^{\mathrm{a}}$ \\
\hline
\end{tabular}

Different letters show significant difference at $\mathrm{p}<0.05$ level.

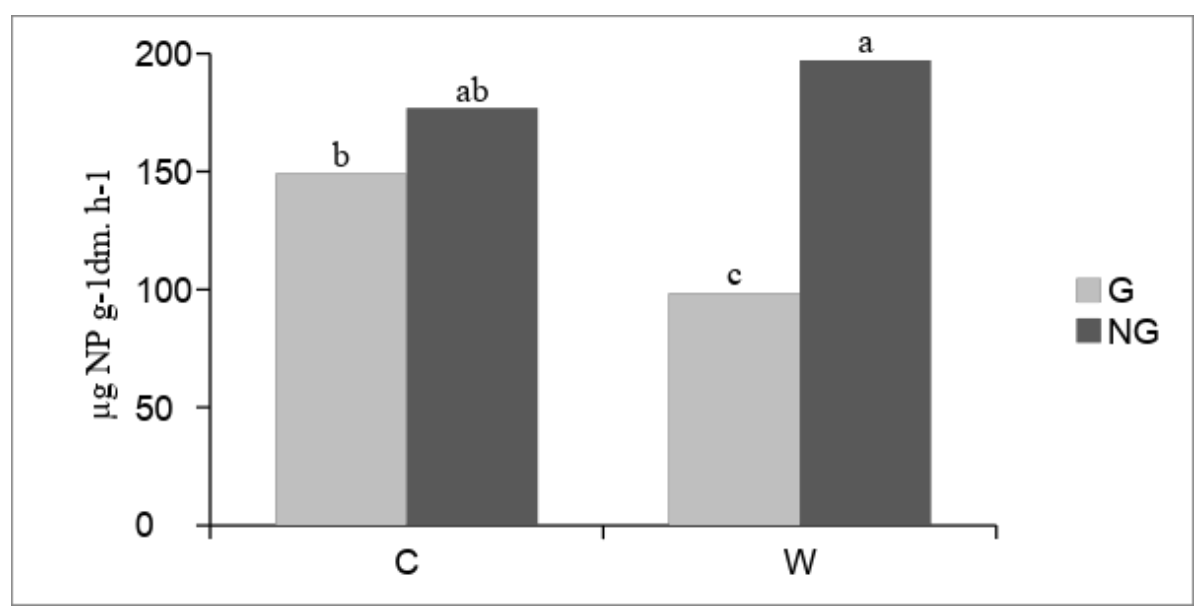

Figure 4. The significant effect of site $(C=$ cold, $W=$ warm $)$ and grazing $(G=$ grazed, $N G=$ not grazed) interaction on $\beta$-glucosidase activity. Different letters show significant difference at $P<0.05$ level 
There was similar trend in invertase activity, as its activity decreased by 76 and $28 \%$ in warm site and autumn samples (Tables 5 and 6 ).

Measurement of urease activity showed that only the season caused significant difference on its activity (Table 5). The urease activity decreased by $29 \%$ in autumn samples in compared with spring samples (Table 6).

The effect of site and season was significant $(\mathrm{p}<0.01)$ on arylsulfatase activity (Table 5). As shown in Table 6, there was a decrease in value of arylsulfatase activity in warm site (17.5\%) and spring samples (17\%).

\section{The correlation between soil properties and enzyme activities}

According to Pearson correlation coefficient values, soil electrical conductivity did not show any correlation with other soil chemical properties (Table 7). Soil $\mathrm{pH}$ correlated negatively with soil available phosphorus and soil moisture (Table 7). Whereas the correlation between soil organic carbon and total nitrogen was positive $(\mathrm{r}=0.774, \mathrm{p}<0.001)$, they correlated negatively with soil moisture (Table 7).

The Pearson correlation indicated no significant correlation between soil EC and enzyme activities (Table 7). Whereas there was no correlation between soil $\mathrm{pH}$ and alkaline phosphatase activity, other assayed enzyme activities correlated negatively with soil $\mathrm{pH}$ except for arylsulfatase (Table 7). The correlation between soil available phosphorous and enzyme activities was positive except for urease and arylsulfatase activity. Total nitrogen showed positive correlation with alkaline phosphatase and arylsulfatase activity (Table 7) with higher correlation with arylsulfatase activity $(\mathrm{r}=0.609, \mathrm{p}<0.001)$. The activity of all assayed enzymes correlated positively with SOC contents (Table 7). The highest correlation was observed with arylsulfatase activity $(\mathrm{r}=0.630, \mathrm{p}<0.001)$. Based on Pearson values, soil moisture positively correlated with acid phosphatase, $\beta$-glucosidase, invertase and urease activity (Table 7 ) except for arylsulfatase activity $(r=-0.689 . \mathrm{p}<0.001)$.

\section{Discussion}

In this study, 11 soil variables including soil chemical properties and enzyme activities were measured to determine soil quality in a semiarid area.

Soil $\mathrm{pH}$ and EC are known as the principal indicator of the chemical characteristic of a particular soil, playing significant role in soil biogeochemical processes, solubility of soil nutrients, plant growth, microbial growth and enzyme activities (Aciego Pietri and Brookes, 2008; Sinsabaugh et al., 2008). Our results indicated that some of soil chemical properties did not easily change, which supported by other studies (Zarekia et al., 2012; Mureithi et al., 2014; Vargas-Gastelum et al., 2015). The less value of $\mathrm{pH}$ in spring samples can be explained by production of $\mathrm{CO}_{2}$ by plant roots and bacteria that temporarily lower the $\mathrm{pH}$ value in natural ecosystem (Subba Rao, 2009).

Available phosphorus (AP), total nitrogen (TN) and soil organic carbon (SOC) are used as important indicators of soil fertility and long-term ecosystem sustainability (da Silva et al., 2008; Wienhold et al., 2009). There are some evidences that plant cover slows losing nutrients from soil (Porder and Chadwick, 2009; Deekor et al., 2012), supporting more TN, AP and SOC content in cold sites with dense plant cover in comparison with warm sites. The less concentrations of SOC at warm sites is attributed to faster turnover of organic $\mathrm{C}$ in warm sites and negative correlation between temperature and soil organic carbon (Friedlingstein et al., 2006). Whereas there was no 
seasonal variation in SOC content, $\mathrm{TN}$ and AP changed seasonally. The temporal alteration of available $\mathrm{P}$ was contradictory to total nitrogen seasonality. Plants uptake more $\mathrm{P}$ with increasing temperature (Yan et al., 2012), depleting the available phosphorus in soil from spring to autumn which is in accordance with our results. The more $\mathrm{TN}$ in autumn can be related to more activity of nitrogen fixing bacteria, which possibly increase the TN content (Zeng et al., 2009). In general, seasonal differences in $\mathrm{AP}$ and other nutrients are due to change in soil $\mathrm{pH}$, moisture and temperature (Turner et al., 2013).

Table 7. Correlation values for soil chemical properties and enzyme activities

\begin{tabular}{|c|c|c|c|c|c|c|c|c|c|c|c|c|}
\hline Variables & EC & pH & TN & $\mathbf{A P}$ & SOC & SM & ACP & ALP & $\beta G$ & IN & UR & AS \\
\hline $\mathrm{EC}$ & 1 & 0.015 & -0.096 & -0.022 & -0.035 & 0.142 & -0.008 & -0.053 & -0.009 & 0.065 & -0.123 & -0.172 \\
\hline $\mathrm{pH}$ & 0.015 & 1 & 0.089 & $-0.340^{* *}$ & -0.110 & $-0.567^{* * * *}$ & $-0.835^{* * *}$ & 0.595 & $-0.709^{* * * * *}$ & $-0.702^{* * *}$ & $-0.312^{*}$ & $0.290^{*}$ \\
\hline $\mathrm{AP}$ & -0.022 & $-0.340^{* *}$ & 0.078 & 1 & 0.206 & 0.097 & $0.344^{* *}$ & $0.457^{* *}$ & $0.414^{* *}$ & $0.479^{* * *}$ & 0.157 & 0.155 \\
\hline $\mathrm{TN}$ & -0.096 & 0.089 & 1 & 0.078 & $0.774^{* * *}$ & $-0.564^{* * *}$ & 0.059 & $0.365^{* *}$ & 0.053 & 0.192 & -0.178 & $0.609^{* * *}$ \\
\hline SOC & -0.035 & -0.110 & $0.774^{* * *}$ & 0.206 & 1 & $-0.508^{* * *}$ & $0.189^{*}$ & $0.524^{* * * *}$ & $0.274^{*}$ & $0.384^{* *}$ & $0.023^{*}$ & $0.630^{* * *}$ \\
\hline SM & 0.142 & $-0.567^{* * *}$ & $-0.564^{* * *}$ & 0.097 & $-0.508^{* * * *}$ & 1 & $0.568^{* * *}$ & 0.040 & $0.321^{* *}$ & $0.305^{*}$ & $0.307^{*}$ & $-0.689^{* * *}$ \\
\hline $\mathrm{ACP}$ & -0.008 & $-0.835^{* * *}$ & 0.059 & $0.344^{* *}$ & $0.189^{*}$ & $0.568^{* * *}$ & 1 & $0.681^{* * *}$ & $0.683^{* * *}$ & $0.784^{* * *}$ & $0.308^{*}$ & -0.232 \\
\hline ALP & -0.053 & $-0.595^{* * *}$ & $0.365^{* *}$ & $0.457^{* *}$ & $0.524^{* * * *}$ & 0.040 & $0.681^{* * *}$ & 1 & $0.578^{* * *}$ & $0.706^{* * *}$ & 0.172 & $0.316^{*}$ \\
\hline BG & -0.009 & $-0.709^{* * *}$ & 0.053 & $0.414^{* *}$ & $0.274^{*}$ & $0.321^{* *}$ & $0.683^{* * *}$ & $0.578^{* * *}$ & 1 & $0.709^{* * *}$ & 0.222 & -0.068 \\
\hline IN & 0.065 & $-0.702^{* * * *}$ & 0.192 & $0.479^{* * * *}$ & $0.384^{* *}$ & $0.305^{*}$ & $0.784^{* * *}$ & $0.706^{* * *}$ & $0.709^{* * * *}$ & 1 & 0.151 & 0.020 \\
\hline UR & -0.123 & $-0.312^{*}$ & -0.178 & 0.157 & 0.023 & $0.307^{*}$ & $0.308^{*}$ & 0.172 & 0.222 & 0.151 & 1 & -0.148 \\
\hline AS & -0.172 & $0.290^{*}$ & $0.609^{* * *}$ & 0.155 & $0.630^{* * *}$ & $-0.689^{* * *}$ & -0.232 & $0.316^{*}$ & -0.068 & 0.020 & -0.148 & 1 \\
\hline
\end{tabular}

$*, * *$ and $* * *$ indicate significant correlation at $\mathrm{p}<0.05, \mathrm{p}<0.01$ and $\mathrm{p}<0.001$, respectively. EC: electrical conductivity, AP: available phosphorus, TN: total nitrogen, SOC: soil organic carbon, SM: soil moisture, ACP: acid phosphatase, AlP: alkaline phosphatase, $\beta$-Glu: $\beta$-glucosidase, INV: invertase, UR: urease and AS: arysulfatase.

The soil enzyme activities is the metrics predominantly used to provide information on soil quality. We studied the activity of six extracellular enzymes, involved in P, C, N and $\mathrm{S}$ cycling. Soil phosphatases play a major role in the mineralization processes of organic phosphorus substrates. The activity of alkaline phosphatase was more than acid phosphatase, possibly related to soil $\mathrm{pH}(>7)$, which makes condition more favourable for alkaline phosphatase activity than acid phosphatase activity. Whereas phosphatases show $\mathrm{pH}$-dependent activity profile, with specific optimum $\mathrm{pH}$ for their maximum activity and stability, only acid phosphatases showed strong negative correlation $(\mathrm{r}=-0.835, \mathrm{p}<0.001)$ with soil $\mathrm{pH}$. The soil $\mathrm{pH}$ values in studied areas were in the range of near optimum $\mathrm{pH}$ for the alkaline phosphatase activity, explaining why this enzyme did not correlate with soil pH (Olander and Vitousek, 2000; Renella et al., 2007).

The positive correlation between alkaline and acid phosphatase activity with SOC and available $\mathrm{P}$ is attributed to more activity of these enzymes in cold sites. Generally, a positive correlation is expected between enzyme activities and soil organic carbon, increasing soil enzyme activities as organic carbon increase in soil. The major reason for increased enzyme activities with increasing soil organic carbon could be attributed to the greater availability of soluble organic $\mathrm{C}$, nutrients which stimulate microbial growth and activity as main source of soil enzymes (Debnath et al., 2015). Although 
our results showed a positive correlation between available $\mathrm{P}$ content and both phosphatase activities, this relationship is usually complicated and not constant, since a positive, a negative or no relationship between them has been reported (Kang et al., 2009; Lemanowicz et al., 2011; Piotrowska-Długosz and Wilczewski, 2014). A significant and positive relationship between phosphatase activity and available phosphorus is observed usually in natural soils and those with a low content of nutrients, where phosphorus deficiency occurs (Šarapatka, 2003). Furthemore, the uptake of available phosphorus by plants may complicate this correlation. The observed positive correlation between total nitrogen and alkaline phosphatase is supported by Piotrowska-Dlugosz and Wilczewski (2014) and Shi et al. (2008) findings. The significant and positive correlation between the acid phosphatase activity and the soil moisture is in agreement with Zheng et al. (2015) and but in contrast with Brockett et al. (2012) findings. The soil moisture content, by altering conditions for soil microbiota, causes changes in soil microbial growth and enzyme activities (Kim et al., 2008; Borowik and Wyszkowska, 2016).

Invertase and $\beta$-glucosidase play critical role in $\mathrm{C}$ cycle and release low molecular weight sugars that are important as energy sources for microorganisms. The positive correlation between $\beta$-glucosidase and invertase activity with soil $\mathrm{pH}$ was in consistent with other studies (Piotrowska and Koper, 2010; Shao et al., 2015; Zhang et al., 2015). Although a negative or no correlation between soil $\mathrm{pH}$ and invertase and $\beta$-glucosidase activity has been reported (Shi et al., 2008; Tan et al., 2014). The positive correlation between $\beta$-glucosidase and invertase activity with soil phosphorus is in agreement with Zheng et al. (2015) and Cheng et al. (2013). $\beta$-glucosidase and invertase activity were positively correlated with the soil organic carbon content. Similarity, Shi et al. (2008), and Böhme and Böhme (2006) observed significant and positive correlation between $\beta$ glucosidase and invertase activities with organic carbon content in soil samples, indicating the important role of organic matter in maintaining their activities. In addition, the observed positive correlation between soil organic matter and available phosphorus with invertase and $\beta$-glucosidase can explain more activity of these enzymes in cold sites, which is in agreement with various studies (Böhme and Böhme, 2006; Shi et al., 2008; Piotrowska and Koper, 2010). Our results did not confirm any significant correlation between soil total nitrogen and $\beta$-glucosidase and invertase, which is in agreement with Shi et al. (2008) and Zheng et al. (2015) but in contrast with Cheng et al. (2013) and Zhang et al. (2015) findings.

Urease is associated with the transformation, biological turnover and bioavailability of nitrogen in soil (Piotrowska-Długosz and Wilczewski, 2014). According to our results, there was a correlation between soil urease activity with soil $\mathrm{pH}(\mathrm{r}=-0.312$, $\mathrm{p}<0.05)$, soil organic carbon $(\mathrm{r}=0.023, \mathrm{p}<0.05)$, total nitrogen $(\mathrm{r}=0.178, \mathrm{p}<0.05)$ and soil moisture $(\mathrm{r}=0.307, \mathrm{p}<0.05)$. Similar results have been reported by Tan et al. (2014), Zhang et al. (2013), and Piotrowska-Dlugosz and Wilczewski (2014). Soil urease activity did not show any correlation with soil EC and available phosphorus, which is in agreement with Melero et al. (2006) and Tan et al. (2014) findings.

Arylsulfatase activity, involved in $\mathrm{S}$ cycle, had a significant correlation with soil $\mathrm{pH}$ $(r=0.290, p<0.05)$, soil organic carbon $(r=0.630, p<0.001)$, total nitrogen $(r=0.609$, $\mathrm{p}<0.001)$ and soil moisture $(\mathrm{r}=-0.689, \mathrm{p}<0.001)$ which are supported by Mankolo et al. (2012) and Green et al. (2007). The strong positive correlation between SOC and arylsulfatase highlights the important role of soil organic carbon in arylsulfatase activity (Mankolo et al., 2012). 
There is no constant pattern in seasonal variation in soil enzyme activities, depending on assayed enzymes, soil properties and ecosystem types. The enzyme seasonal variation is governed by parameters that regulate enzyme activities such as soil temperature, moisture and substrate availability (Wittmann et al., 2004; Niemi et al., 2005; Baldrian et al., 2008). Although seasonal variations in enzyme activities was not supported by Boerner et al. (2005) and Wallenstein et al. (2008), there was seasonal variation in all studied enzymes. The observed seasonal variation in acid and alkaline phosphatase, $\beta$-glucosidase, invertase and urease can be explained by more plant root exudates and seasonal variation in the microbial biomass which is in agreement with Devi and Yadava (2006), Yang et al. (2010) and Wallenstein and Weintraub (2008) findings. The all enzymes had more activity in spring except for arylsulfatase activity. Our finding on more intense activity of arylsulfatase in autumn is opposite with Margesin et al. (2014) report, but can be supported by Whalen and Warman (1996) findings. The more arylsulfatase activity in autumn samples can be related to presence of non-competitive inhibitors, possibly removed by plants during growth season and increasing arylsulfatase activity in autumn samples (Whalen and Warman, 1996).

Although the soil enzyme activities values were more in grazed area but the difference was not significant between grazed and not grazed areas except for alkaline phosphatase activity, showing its more sensitivity to environmental changes. It has been approved that the effect of grazing on soil properties depends on grazing intensity and period (Steffens et al., 2008; Fang et al., 2013).

\section{Conclusion}

It has been accepted that soil chemical properties and enzyme activities are important indicators in soil quality assessment. This study was conducted to illustrate the effect of site, season and grazing on soil chemical properties and enzyme activities. The results revealed the significant influence of site and season on some of soil chemicals and extracellular enzymes activities in semiarid areas but not grazing. The higher activity of all assayed enzyme activity in soils at cold sites can be attributed to the more soil organic carbon as there was a positive correlation between SOC and all assayed enzymes except for urease. There were also significant seasonal dynamics among different enzyme activities. Among the enzymes studied alkaline phosphatase was affected by grazing, which shows its higher sensitivity to soil management. In conclusion, it seems the soil quality is poor in warm sites according to both soil chemical and enzyme activities. Then soil in warm sites are more vulnerable to degradation and need more concern to be protected.

Acknowledgements. This project was financed by Research Institute of Forests and Rangelands and Vice Chancellor of Alzahra University (D96/3/125).

\section{REFERENCES}

[1] Aciego Pietri, J. C. A., Brookes, P. C. (2008): Nitrogen mineralisation along a pH gradient of a silty loam UK soil. - Soil Biology and Biochemistry 40(3): 797-802.

[2] Amiraslani, F., Dragovich, D. (2011): Combating desertification in Iran over the last 50 years: An overview of changing approaches. - Journal of Environmental Management 92(1): 1-13. 
[3] Bagheri, R., Saravi, M., Chaeichi, M. R. (2009): Effect of grazing intensity on some soil chemical properties in a semi arid region (case study: Khabr National Park and near rangelands). - Rangeland 3(3): 398-412.

[4] Baldrian, P., Trögl, J., Frouz, J., Šnajdra, J., Valášková, V., Merhautová, V., Cajthaml, T., Herinková, J. (2008): Enzyme activities and microbial biomass in topsoil layer during spontaneous succession in spoil heaps after brown coal mining. - Soil Biology and Biochemistry 40(9): 2107-2115.

[5] Baldrian, P., Stursová, M. (2010): Enzymes in Forest Soils. - In: Shukla, G., Varma, A. (eds.) Soil Enzymology. Springer-Verlag, Berlin, Heidelberg.

[6] Boerner, R. E. J. Brinkman, J. A., Smith, A. (2005): Seasonal variations in enzyme activity and organic carbon in soil of a burned and unburned hardwood forest. - Soil Biology and Biochemistry 37: 1419-1426.

[7] Böhme, L., Böhme, F. (2006): Soil microbiological and biochemical properties affected by plant growth and different long-term fertilization. - European Journal of Soil Biology 42(1): 1-12.

[8] Borowik, A., Wyszkowska, J. (2016): Soil moisture as a factor affecting the microbiological and biochemical activity of soil. - Plant Soil and Environment 62(6): 250-255.

[9] Bremner, J. M. Mulvaney, C. S. (1982): Nitrogen-Total. - In: Page, A. L., Miller, R. H., Keeney, D. R. (eds.) Methods of Soil Analysis. Part 2. Chemical and Microbiological Properties. American Society of Agronomy \& Soil Science Society of America, Madison, WI.

[10] Brockett, B. F. T., Prescott, C. E., Graysto, S. J. (2012): Soil moisture is the major factor influencing microbial community structure and enzyme activities across seven biogeoclimatic zones in western Canada. - Soil Biology and Biochemistry 44(1): 9-20.

[11] Cheng, F., Peng, X., Zhao, P., Yuan, J., Zhong, C., Cheng, Y., Cui, C., Zhang, S. (2013): Soil microbial biomass, basal respiration and enzyme activity of main forest types in the Qinling Mountains. - PloS One 8(6): e67353.

[12] Da Silva, M. A. G., Pavan, M. A., Muniz, A. S., Tonin, T. A., Pelizer, T. (2008): Nutrient availability in soil and its absorption, transport, and redistribution in vines. Communications in Soil Science and Plant Analysis 39(9-10): 1507-1516.

[13] Das, S. K., Varma, A. (2010): Role of Enzymes in Maintaining Soil Health. - In: Shukla, G., Varma, A. (eds.) Soil Enzymology. Soil Biology 22. Springer-Verlag, Berlin, Heidelberg.

[14] Debnath, S., Patra, A. K., Ahmed, N., Kumar, S., Dwivedi, B. S. (2015): Assessment of microbial biomass and enzyme activities in soil under temperate fruit crops in northwestern Himalayan region. - Journal of Soil Science and Plant Nutrition 15(4): 848866.

[15] Deekor, T. N., Iwara, A. I., Ogundele, F. O., Amiolemen, S. O., Ita, A. E. (2012): Changes in soil properties under different land use covers in parts of Odukpani, Cross River State, Nigeria. - Journal of Environmental Ecology 3(1): 88-94.

[16] Devi, N. B., Yavada, D. P. (2006): Seasonal dynamics in soil microbial biomass C, N and $\mathrm{P}$ in a mixed oak forest ecosystem of Manipur, North-east India. - Applied Soil Ecology 31(3): 220-227.

[17] Fang, Y., Li, X., Chen, C. C., Zhang, M., Zhou, R. P., Gao, T. M., Zhang, R. Q., Hai, C. X. (2013): The impact of different grazing intensity on topsoil physical and chemical properties in Xilamuren grassland. - Applied Mechanics and Materials 295-298: 20902096.

[18] Friedlingstein, P., Cox, P., Betts, R., Bopp, L., von Bloh,, Brovkin, V., Cadule, P., Doney, S., Eby, M., Fung, I., Bala, G., John, J., Jones, C., Joos, F., Kato, T., Kawamiya, M., Knorr, W., Lindsay, K., Matthews, H. D., Raddatz, T., Rayner, P., Reick, C, Roeckner, E., K., Schnitzler, G., Schnur, R., Strassmann, K., Weaver, A. J., Yoshikawa, 
C., Zeng, N. (2006): Climate-carbon cycle feedback analysis: results from the (CMIP)-M4 model intercomparison. - Journal of Climate 19: 3337-3353.

[19] Green, V. S.; Scott, D. E.; Cruz, J. C.; Curi, N. (2007): Tillage impacts on soil biological activity and aggregation in a Brazilian Cerrado Oxisol. - Soil andTillage Research 92(12): $114-121$.

[20] Kabiri, V., Raiesia, F., Ghazavi, M. A. (2016): Tillage effects on soil microbial biomass, som mineralization and enzyme activity in a semi-arid calcixerepts. - Agriculture, Ecosystems and Environment 232: 73-84.

[21] Kandeler, E., and Gerber, H. (1988): Short term assay of urease activity using colorimetric determination of ammonium. - Biology and Fertility of Soils 6(1): 68-72.

[22] Kang, H., Kang, S., Lee, D. (2009): Variations of soil enzyme activities in a temperate forest soil. - Ecological Research 24(5): 1137-1143.

[23] Kim, S. Y., Lee, S. H., Freeman, C., Fennerb, N., Kang, H. (2008): Comparative analysis of soil microbial communities and their responses to the short-term drought in bog, fen, and riparian wetlands. - Soil Biology and Biochemistry 40(11): 2874-2880.

[24] Lemanowicz, J. (2011): Phosphatases activity and plant available phosphorus in soil under winter wheat (Triticum aestivum L.) fertilized minerally. - Polish Journal of Agronomy 4(1): 12-15.

[25] Mankolo, R., Reddy, C., Senwo, Z., Nyakatawa, E., Sajjala, S. (2012): Soil biochemical changes induced by poultry litter application and conservation tillage under cotton production systems. - Agronomy 2(3): 187-198.

[26] Margesin, R., Minerbi, S., Schinner, F. (2014): Long-term monitoring of soil microbiological activities in two forest sites in South Tyrol in the Italian Alps. Microbes and Environments 29(3): 277-285.

[27] McLean, E. O. (1982): Soil pH and Lime Requirement. - In: Page, A. L., Miller, R. H., Keeney, D. R. (eds.) Methods of Soil Analysis. Part 2. Chemical and Microbiological Properties. American Society of Agronomy \& Soil Science Society of America, Madison, WI.

[28] Melero, S., Ruiz Porras, J. K., Herencia, J. F., Madejonm, E. (2006): Chemical and biochemical properties in a silty loam soil under conventional and organic management. Soil and Tillage Research 90(1): 162-170.

[29] Mirzaei, J., Heydari, M., Prevosto, B. (2017): Effects of vegetation patterns and environmental factors on woody regeneration in semi-arid oak-dominated forests of western Iran. - Journal of Arid Land 9(3): 368-378.

[30] Mureithi, S. M., Verdoodt, A., Gachene, C. K. K., Njoka, J. T., Wasonga, V. O., De Neve, S., Meyerhoff, E., Van Ranst, E. (2014): Impact of enclosure management on soil properties and microbial biomass in a restored semi-arid rangeland, Kenya. - Journal of Arid Land 6: 561-570.

[31] Najmizadeh, S., Yavari, A. (2006): Zoning and planning of Khabr national park with the aid of GIS. - Journal of Environmental Studies 31(38): 47-58 [in Persian].

[32] Niemi, R. M., Vepsäläinen, M., Wallenius, K., Simpanena, S., Alakukkub, L., Pietola, L. (2005): Temporal and soil depth-related variation in soil enzyme activities and in root growth of red clover (Trifolium pratense) and timothy (Phleum pratense) in the field. Applied Soil Ecology 30(2): 113-125.

[33] Olsen, S. R., Sommers, L. E. (1982): Phosphorus. - In: Page, A. L., Miller, R. H., Keeney, D. R. (eds.) Methods of Soil Analysis. Part 2. $2^{\text {nd }}$ ed. Chemical and Microbiological Properties. American Society of Agronomy \& Soil Science Society of America, Madison, WI.

[34] Piotrowska, A., Koper, J. (2010): Soil $\beta$-glucosidase activity under winter wheat cultivated in crop rotation systems depleting and enriching the soil in organic matter. Journal of Elementology 15(3): 593-600. 
[35] Piotrowska-Długosz, A., Wilczewski, E. (2014): Assessment of soil nitrogen and related enzymes as influenced by the incorporation time of field pea cultivated as a catch crop in Alfisol. - Environmental Monitoring and Assessment 186(12): 8425-8441.

[36] Porder, S., Chadwick, O. A. (2009): Climate and soil-age constraints on nutrient uplift and retention by plants. - Ecology 90(3): 623-636.

[37] Raiesi, F., Riahi, M. (2014): The influence of grazing exclosure on soil C stocks and dynamics, and ecological indicators in upland arid and semi-arid rangelands. - Ecological Indicators 41: 145-154.

[38] Rajabi, M., Lotfalizadeh, H., Madjdzadeh, M. (2011). The family chalcididae (hym. chalcidoidea) from Kerman Province, southeastern Iran with some new records. - Acta Zooligica Bulgarica 63(3): 263-268.

[39] Renella, G., Szukcis, U., Landi, L., Nannipieri, P. (2007): Quantitative assessment of hydrolase production and persistence in soil. - Biology and Fertility of Soils 44(2): 321329.

[40] Reyes-Reyes, B. G., Alcántara-Hernández, R., Rodríguez, V., Olalde-Portugal, V., Dendoovenc, L. (2007): Microbial biomass in a semi-arid soil of the central highlands of Mexico cultivated with maize or under natural vegetation. - European Journal of Soil Biology 43(3): 180-188.

[41] Šarapatka, B. (2003): Phosphatase Activities (ACP, ALP) in Agroecosystem Soils. Ecology and Crop Production Science PhD Thesis. Swedish University of Agricultural Sciences, Uppsala.

[42] Schlichting, E., Blume, H. P. (1966): Bodenkundliches Praktikum. - Paul Parey, Hamburg.

[43] Schinner, F., von Mersi, W. (1990): Xylanase, CM-cellulase and invertase activity in soil, as improved method. - Soil Biology and Biochemistry 22(4): 511-515.

[44] Schinner, F., Öhlinger, R., Kandeler, E., Margesin, R. (1996): Methods in Soil Biology. Springer-Verlag, Berlin, Heidelberg.

[45] Shao, X., Yang, W., Wu, M. (2015): Seasonal dynamics of soil labile organic carbon and enzyme activities in relation to vegetation types in Hangzhou Bay tidal flat wetland. PloS One 10(11): e0142677. https://doi.org/10.1371/journal.pone.0142677.

[46] Sharafatmandrad, M., Sepehry, A., Barani, H. (2014): Plant species and functional types' diversity in relation to grazing in arid and semi-arid rangelands, Khabr national park, Iran. - Journal of Rangelands Science 4(3): 203-214.

[47] Shi, Z. J., Lu, Y., Xu, Z. G., Fu, S. L. (2008): Enzyme activities of urban soils under different land use in the Shenzhen city, China. - Plant Soil and Environment 54(8): 341346.

[48] Shirvani, A. (2012): Noctuidae (Lepidoptera) species sampled from Khabr national park, Kerman, Iran part I. - Journal of the Lepidopterists' Society 66(3): 121-132.

[49] Sinsabaugh, R. L., Lauber, C. L., Weintraub, M. N., Ahmed, B., Allison, S. D., Crenshaw, C., Contosta, A. R, Cusack, D., Frey, S., Gallo, M. E., Gartner, T. B., Hobbie, S.E, Holland, K., Keeler, B. L., Powers, J. S., Stursova, M., Takacs-Vesbach, C., Waldrop, M. P., Wallenstein, M. D., Zak, D. R., Zeglin, L. H. (2008): Stoichiometry of soil enzyme activity at global scale. - Ecology Letters 11(11): 1252-1264.

[50] Subba Rao, N. S. (2009): Soil Microbiology. - Oxford and IBH Publishing Pvt. Ltd., New Delhi.

[51] Steffens, M., Kölbl A, Totscheb, K.U, Kögel-Knabnera, I. (2008): Grazing effects on soil chemical and physical properties in a semiarid steppe of Inner Mongolia (P. R. China). Geodema 143(1-2): 63-79.

[52] Tan, X., Xie, B., Wang, J., He, W., Wang, X., Wei, G. (2014): County-scale spatial distribution of soil enzyme activities and enzyme activity indices in agricultural land: implications for soil quality assessment. - Scientific World Journal 2014: 535768. doi: $10.1155 / 2014 / 535768$. 
[53] Toogood, J. A. (1958): A simplified textural classification diagram. - Canadian Journal of Soil Science 38(1): 54-55.

[54] Trasar-Cepeda, C., Leirós, M. C., Gil-Sotres, F. (2008): Hydrolytic enzyme activities in agricultural and forest soils. Some implications for their use as indicators of soil quality. Soil Biology and Biochemistry 40(9): 2146-2155.

[55] Turner, B. L., Yavitt, J. B. Harms, K. E., Ancon, B., Garcia, M. N., Romero, T. E., Wright, S. J. (2013): Seasonal changes and treatment effects on soil inorganic nutrients following a decade of fertilizer addition in a lowland tropical forest. - Soil Science Society of America Journal 77: 1357-1369.

[56] Vargas-Gastelum, L., Romero-Olivares, A. L., Escalante, A. E., Rocha-Olivares, A., Brizuela, C., Riquelme, M. (2015): Impact of seasonal changes on fungal diversity of a semi-arid ecosystem revealed by 454 pyrosequencing. - FEMS. Microbiology Ecology 91(5): pii: fiv044.

[57] Walkley, A., Black, I. A. (1934): An examination of the Degtjareff method for determining organic carbon in soils: Effect of variations in digestion conditions and of inorganic soil constituents. - Soil Science 63: 251-263.

[58] Wallenstein, M. D., Weintraub, M. N. (2008): Emerging tools for measuring and modeling the in situ activity of soil extracellular enzymes. - Soil Biology and Biochemistry 40(9): 2098-2106.

[59] Wallenstein, M. D., Mcmahon, S. K., Schime, J. P. (2008): Seasonal variation in enzyme activities and temperature sensitivities in Arctic tundra soils. - Global Change Biology 15: 1631-1639.

[60] Wittmann, C., Kahkonen, M. A., Ilvesniemi, H., Kurola, J., Salkinoja-Salonena, M. S. (2004): Areal activities and stratification of hydrolytic enzymes involved in the biochemical cycles of carbon, nitrogen, sulphur and phosphorus in podsolized boreal forest soils. - Soil Biology and Biochemistry 36(3): 425-433.

[61] Whalen, J. K., Warman, P. R. (1996): Arylsulfatase activity in soil and soil extracts using natural and artificial substrates. - Biology and Fertility of Soils 22(4): 373-378.

[62] Wienhold, B. J., Karlen, D. L., Andrews, S. S., Stot, D. E. (2009): Protocol for soil management assessment framework (SMAF) soil indicator scoring curve development. Renewable Agriculture and Food Systems 24(4): 260-266.

[63] Yan, Q., Duan, Z., Mao, J., Li, X., Dong, F. (2012): Effects of root-zone temperature and $\mathrm{N}, \mathrm{P}$, and $\mathrm{K}$ supplies on nutrient uptake of cucumber (Cucumis sativus L.) seedlings in hydroponics. - Soil Science and Plant Nutrition 58(6): 707-717.

[64] Yang, K., Zhu, J., Zhang, M., Yan, Q., Sun, Q. J. (2010): Soil microbial biomass carbon and nitrogen in forest ecosystems of Northeast China: A comparison between natural secondary forest and larch plantation. - Journal of Plant Ecology 3(3): 175-182.

[65] Zarekia, S., Jafari, M., Arzani, H., Javadi, S. A., Jafari, A. A. (2012): Grazing effects on some of the physical and chemical properties of soil. - World Applied Science Journal 20(2): 205-212.

[66] Zeng, H. D., Hu, Y. L., Chang, S. X., Fan, Z. P. (2009): Land cover change effects on soil chemical and biological properties after planting Mongolian pine (Pinus sylvestris var. mongolica) in sandy lands in Keerqin, northeastern China. - Plant and Soil 317(1-2): 121-133.

[67] Zhang, L., Chen, W., Burger, M., Yang, L., Gong, P., Wu, Z. (2015): Changes in soil carbon and enzyme activity as a result of different long-term fertilization regimes in a greenhouse field. - PloS One 10(2): e0118371. doi: 10.1371/journal.pone.0118371.

[68] Zhang, T., Wan, S., Kang, Y., Feng, H. (2013): Urease activity and its relationships to soil physiochemical properties in a highly saline-sodic soil. - Journal of Soil Science and Plant Nutrition 14(2): 314-315.

[69] Zheng, M., Huang, J., Chen, H., Wang, H., Mo, J. (2015): Responses of soil acid phosphatase and beta-glucosidase to nitrogen and phosphorus addition in two subtropical forests in southern China. - European Journal of Soil Biology 68: 77-84. 